\title{
An Examination of International Relations Regarding Pacific Bluefin Tuna-With an Implication from the Whaling Issue
}

\author{
Takashi Sekiyama \\ Center for Global Education, Toyo University, Tokyo, Japan \\ Email: sekiyama@toyo.jp
}

How to cite this paper: Sekiyama, T. (2017) An Examination of International Relations Regarding Pacific Bluefin Tuna-With an Implication from the Whaling Issue. Journal of Environmental Protection, 8, 1595-1604

https://doi.org/10.4236/jep.2017.813098

Received: November 20, 2017 Accepted: December 17, 2017

Published: December 21, 2017

Copyright $\odot 2017$ by author and Scientific Research Publishing Inc. This work is licensed under the Creative Commons Attribution International License (CC BY 4.0).

http://creativecommons.org/licenses/by/4.0/

\begin{abstract}
This paper is to present a framework to analyse international relations regarding protection and exploitation of an endangered species. The question of how to balance conservation and consumption in order to maintain the sustainability of resources and nature is not only the central challenge of conservation ecology, but also an international political and economic issue that frequently leads to confrontation between countries. In relation to whales, for example, Japan has long been subjected to criticism by anti-whaling countries such as the United States and Australia, and has faced off against them on the international stage. And, more recently, similar confrontations have begun to appear in relation to tuna and eel. It has been highlighted in recent years that Pacific Bluefin Tuna are becoming endangered, and there is considerable national and international concern with regard to their resource management. This paper first obtains an implication about the course of events that led to the fishing ban. The implication is applied to the case of Pacific Bluefin Tuna. Pacific Bluefin Tuna and the whaling issue reveals points of commonality. The conclusion is that history of the whaling issue implies that Japan will lose the support not only of countries opposed to fishing but also of neutral countries, if Tokyo continues to adopt policies which make light of resource conservation. Even a total ban on the fishing of Pacific Bluefin Tuna may result. This implication from the whaling issue is potentially helpful to predict the development of international relations and conservation regarding other endangered species.
\end{abstract}

\section{Keywords}

Conservation Ecology, Pacific Bluefin Tuna, Whaling, International Relations 


\section{Introduction}

The achievement of the sustainable use of resources and nature is a shared intergenerational problem for international society as a whole. The conservation of resources and nature cannot be taken lightly. At the same time, resources have both consumers and producers, and the reality is that many people would be unable to maintain their lifestyle and culture without using these resources. The question of how to balance conservation and consumption in order to maintain the sustainability of resources and nature is not only the central challenge of conservation ecology, but also an international political and economic issue that frequently leads to confrontation between countries.

In Japan, which has both high consumption of marine products and large numbers of people in the fishing industry, controversies concerning the consumption and conservation of fishery resources frequently come into view, and it is not uncommon that these develop into international confrontations. In relation to whether to prioritize ensuring the consumption of fishery resources, or whether to emphasize their conservation, Japan and other consumer countries stand in opposition to the mainly Western countries that place emphasis upon nature conservation. For example, Japan has long been subjected to criticism by anti-whaling countries such as The United States and Australia, and has faced off against them on the international stage [1]. And, more recently, similar confrontations have begun to appear in relation to tuna and eel.

It has been highlighted in recent years that Pacific Bluefin Tuna, which migrate in Asian Pacific waters, are becoming endangered, and there is considerable national and international concern with regard to their resource management. According to a report by the International Scientific Committee for Tuna and Tuna-like Species in the North Pacific Ocean (hereinafter called "ISC"), Pacific Bluefin Tuna have fallen to a "historic low" of $2.6 \%$ of their unfished size, the resource level that would have existed if humans had not fished them[2]. As shown in Figure 1, Pacific Bluefin Tuna are indeed on the verge of being eaten to extinction [3].

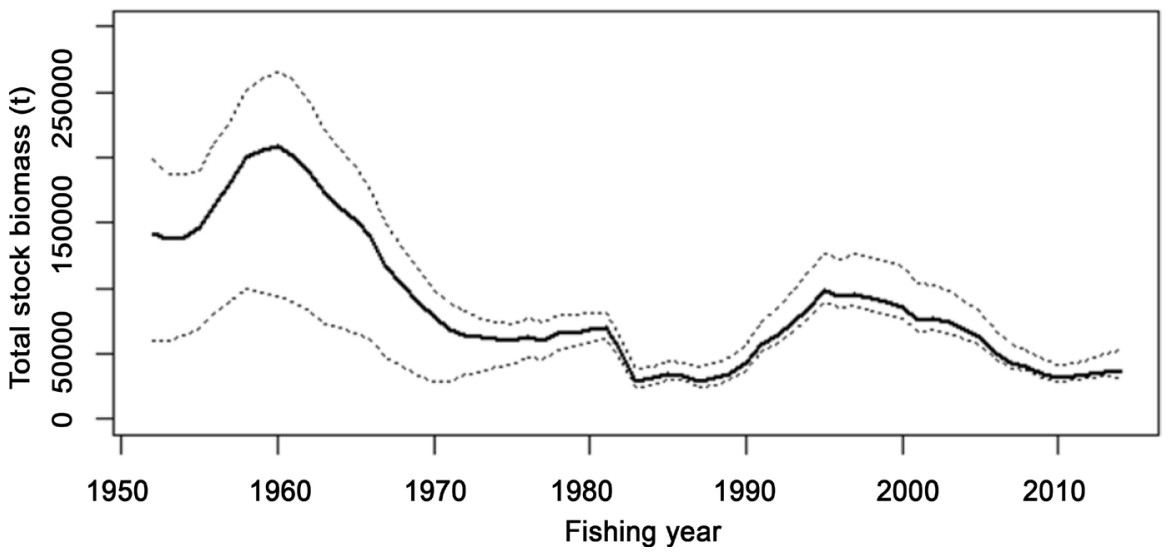

Note: The solid line indicates point estimate and dashed lines indicate the $90 \%$ confidential interval.

Figure 1. Resource situation for mature Pacific Bluefin Tuna [2]. 
Why has the resource level of Pacific Bluefin Tuna fallen so far? Is increased consumption by China behind it? What are the positions of Asia-Pacific countries in relation to the consumption and conservation of Bluefin Tuna? How will international relations develop in relation to Pacific Bluefin Tuna?

This paper considers international relations surrounding Pacific Bluefin Tuna in terms of the consumption and conservation of fishery resources through a comparison with preceding researches in relation to the whaling issue. Below, preceding researches about the course of events that led to commercial whaling ban in 1982 are reviewed, and its implication is presented. Then, the implication is applied to international relations of Asia-Pacific countries in relation to Bluefin Tuna, and the current state of fisheries regulation. Following this, a comparison will be made between Pacific Bluefin Tuna and the whaling issue, highlighting points of commonality between them in terms of international relations regarding the conservation and consumption of fishery resources, and extracting hints regarding the future of international relations concerning Pacific Bluefin Tuna.

\section{Implications Obtained from the Whaling Issue}

Whaling was formerly a major industry in The United States, Europe and Japan, but with the blue whale and other large whale species reaching the brink of extinction, and a decrease in the need for whaling in the post-war period, voices supporting the conservation of whales and in opposition to whaling increased internationally from the 1960s. All of the United States, Europe and Japan share the basic idea that there is a need to manage whale resources to some extent. Nevertheless, they have been in conflict since the 1970s regarding whether or not there is a need for a total ban on commercial whaling. Japan continued to hunt whales for meat rather than oil even after the US and European countries had withdrawn from whaling as they no longer needed whale oil. Consequently, former major whaling countries such as the United States and Australia became opposed to whaling, and Japan and other whaling-promoting countries became the minority in international society. As a result, in 1982, the International Whaling Commission (hereinafter called "IWC") moved to prohibit commercial whaling of large whale species (13 species including blue whales and minke whales), a ban which remains in place today ([1] [4]-[11]).

The following implications can be obtained from preceding researches into the course of events that led to this whaling ban. First, if the fishing of certain fishery resources decreases in a certain country, and industry participants decline, the only opinions that will remain in that country will be those in support of nature conservation, which will call for the conservation of fishery resources; consequently, former fishing countries and consuming countries will flip to become countries that support resource conservation.

Second, under pressure from domestic opinion and nature conservation groups, countries that have come to oppose fishing and promote conservation 
will also go over to the side of opposition to fishing and promotion of conservation with respect to these fishery resources in international society as well.

Third, when countries with an interest in the fishing and consumption of fishery resources become the minority in international society, international rules that are strongly tilted towards resource conservation, in the form of total fishing bans, will be established by majority vote. In particular, when these fishery resources become critically endangered, even countries that have taken a neutral position will come to support resource conservation.

Fourth, once international rules for resource conservation in the form of total fishing bans have been established by majority vote, it is extremely difficult for the fishing and consuming countries, as the minority, to change such rules which have been established in the name of nature conservation. Consideration will be given below as to whether these characteristics gleaned from the whaling issue are applicable to Asia-Pacific international relations surrounding Bluefin Tuna.

\section{International Relations Surrounding Pacific Bluefin Tuna}

With fishery resources such as tuna and eel having sharply declined in recent years, the impact of expanded fishing by China may be highlighted. However, at least in terms of Pacific Bluefin Tuna, the impact of fishing by China is close to zero (see Figure 2). The tuna that China actively fishes are Bigeye Tuna and Yellowfin Tuna, and much of its catch is exported to Japan [12].

It is Japan that fishes and consumes the majority of Bluefin Tuna. The reason that Japan's catch of Pacific Bluefin Tuna significantly expanded in the post-war period is that its Bluefin Tuna industry became active in the North Atlantic Ocean. In the 2011 time frame, out of 21,000 tons total catch of Pacific Bluefin Tuna, $86 \%$ was caught by Japan [13]. Almost $60 \%$ of the catch was consumed by Japan, rising to almost $80 \%$ if fish rapidly raised from small fry are included. In addition, as a result of increased demand caused by the global popularity of sushi and sashimi, fishing by South Korea, Taiwan and Mexico has increased since around the year 2000 .

Until the early 1980s, however, the United States was also a major fisher of Pacific Bluefin Tuna in addition to Japan. The quantity of its catch reached 11,000 tons in some years. However, by the 2000s, the quantity of Pacific Bluefin Tuna caught by The United States had significantly fallen. That quantity is now only some tens or hundreds of tons, the majority of which is a result of recreational fishing, and commercial fishing for Pacific Bluefin Tuna by The United States essentially no longer exists. With the decline of Pacific Bluefin Tuna fishing in its own country, The United States has become an active promoter of fishing controls on Pacific Bluefin Tuna from the perspective of nature conservation. This is comparable to US change of position in relation to whaling. Furthermore, international NGOs such as the Pew Charitable Trusts and Greenpeace are also increasingly interested in the nature conservation of Pacific Bluefin 


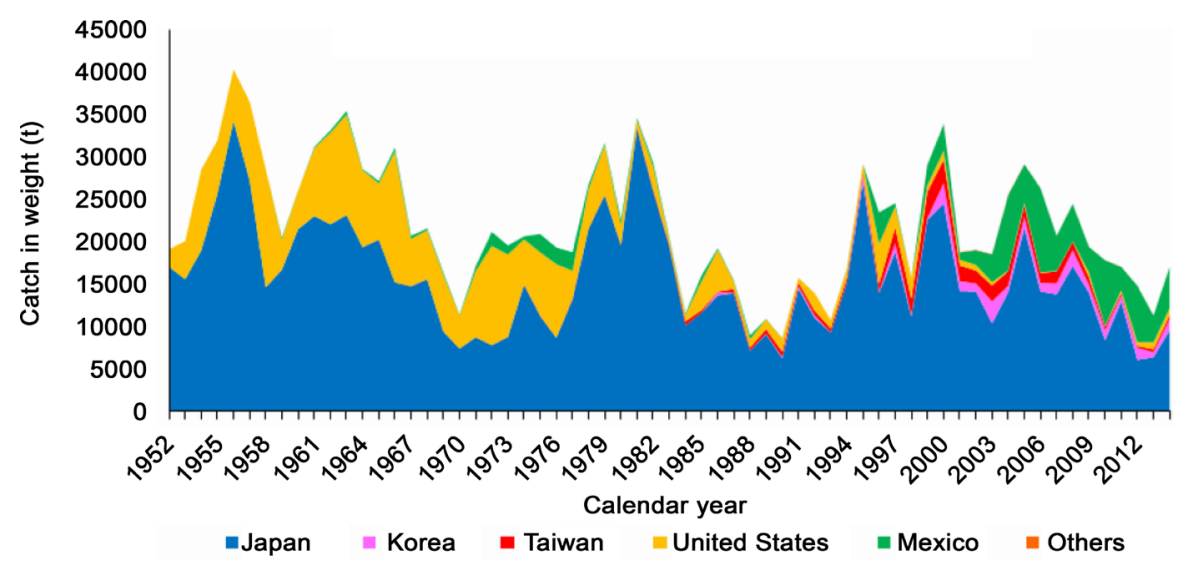

Figure 2. Trend in Pacific Bluefin Tuna catch by country and area [2].

Tuna, and have made moves calling for an immediate halt to its commercial fishing [14].

Thus, international relations concerning Pacific tuna are taking a form in which East Asian fishing-promoting areas centered on Japan, South Korea and Taiwan are opposed by The United States, the EU, Australia, New Zealand, island countries and international NGOs that promote nature conservation and marine resource conservation. This structure also strongly resembles international relations surrounding whaling.

\section{Trends in Fishing Management}

Fish such as tuna that migrate through international waters and the waters of multiple countries are called highly migratory species. One country cannot succeed alone in the resource management of highly migratory species, so international organizations are formed to hold discussions on resource management. In relation to the resource management of Pacific Bluefin Tuna, discussions are held by an international body called the Western and Central Pacific Fisheries Commission (hereinafter called "WCPFC"). WCPFC is an international body with members including Japan, The United States, South Korea, China, Taiwan, Australia and the EU, and holds its plenary session in December each year. In advance of the plenary session, its Northern Committee subsidiary body meets at the end of August each year with a more limited membership of countries, and mainly discusses waters north of the $20^{\text {th }}$ parallel north.

With resource levels of Pacific Bluefin Tuna having fallen to an historic low, WCPFC has established a short term target to raise the probability that resources will rise to their historic median value (the median value of the quantity of mature fish) by 2024 to $60 \%$ or greater. To achieve this target, the member countries of WCPFC are implementing fishing controls which will halve the catch of small fish under $30 \mathrm{~kg}$ from its mean level between 2002 and 2004, and hold the catch of large fish over $30 \mathrm{~kg}$ to the same level.

At the session of the Northern Committee held in Busan, South Korea between the $28^{\text {th }}$ of August and the 1st of September this year, the Japanese Gov- 
ernment proposed relaxing these restrictions to allow catch quotas to be exceeded if the probability of achieving the target rises above $65 \%$. This proposal by the Japanese Government was opposed by The United States and other countries, but it appears that they made slight concessions out of sympathy toward the plight of tuna fishermen in Japanese waters [15].

Ultimately, the Busan session agreed to relax the restrictions to the extent that, while catch quotas would be made stricter if the likelihood of achieving the recovery target fell beneath $60 \%$, catch quotas would be increased if the likelihood was seen to exceed $75 \%$. In addition, the Busan session closed by establishing a long term goal for the recovery of adult fish to $20 \%$ of their unfished size by 2034 [16]. The 14th Regular Session of WCFCP held in Manila, Philippines adopted these looser regulations reported from the Busan session in December 2017 [17].

\section{The Appropriateness of Resource Management Targets}

As to whether resource management targets strike a balance between the consumption and conservation of Pacific Bluefin Tuna, it must be said that they lean too far in the direction of resource consumption. To begin with, although the target level set has been for Pacific Bluefin Tuna to recover to the historic median value of its resource level (the median value of the past quantity of mature fish) by 2024, as considerable fishing of Pacific Bluefin Tuna has occurred since the Meiji era, even the historic median value represents a mere $6 \%$ of the unfished size on the hypothesis of there having never been a fishing industry. In general, management targets for fishery resources are set to be at least $20 \%$ of unfished size, with appropriate levels held to be up to $60 \%$ for some species; in comparison with this, the adoption of a level of only $6 \%$ as the immediate target for Pacific Bluefin Tuna must be said to be extremely low.

Moreover, WCPFC has presently set a management target that allows the probability of resource recovery to the historic median value (the median value of the past quantity of mature fish), which is a low level to begin with, to be as low as $60 \%$ by 2024 . Put another way, this accepts a failure to recover to a mere $6 \%$ of the unfished size four times out of ten, and is clearly insufficient as a recovery plan for an endangered species.

Such weak fishing regulations are a result of the understanding shown by other countries to Japan as a major consumer of Bluefin Tuna, but on this occasion, the Japanese Government proposed relaxing regulations to allow further exceeding catch quotas. Although the terms of the relaxation of regulations were somewhat scaled back in the face of opposition by The United States and other countries, agreement was reached to increase catch quotas if the likelihood of achieving recovery to the historic median value is seen to exceed $75 \%$. As things stand, even recovery to the historic median value, which is a low target to begin with, is in doubt.

One consolation is that the Busan session established a long term target for recovery of mature fish to $20 \%$ of the unfished size by 2034 , but achieving this 
will by no means be easy. At present, recruitment of Pacific Bluefin Tuna (the quantity that is newly able to be caught in a year due to spawning and maturation) is approximately 300 thousand fish, an extremely low level in historical terms (see Figure 3). According to a simulation by ISC, even if recruitment continues to recover to approximately 820 thousand fish, continuation of the current fishing restrictions alone is estimated to give an essentially zero percent likelihood that mature fish will recover to $20 \%$ of the unfished size by 2034 (see Table 1).

The proposal of the Japanese Government to relax fishing restrictions despite this can only be said to be contemptuous of the conservation of Pacific Bluefin Tuna resources. Although the influence of Japan is strong, and the principal Pacific Bluefin Tuna fishing members of the Northern Committee such as South Korea and Taiwan may accept Japan's proposals, the mood of the plenary meeting may differ. As long as the Japanese Government continues to adopt a negative attitude toward the conservation of Pacific Bluefin Tuna, there is a risk that antagonism between Japan, South Korea and Taiwan as fishing promoting areas, and The United States, the EU, Australia, New Zealand and island countries, which promote nature conservation and marine resource conservation, may become increasingly intense.

\section{Comparison with the Whaling Issue}

A comparison between the international relations surrounding Pacific Bluefin Tuna seen above and the whaling issue reveals points of commonality. In relation to cetacean protection, former major whalers such as The United States and

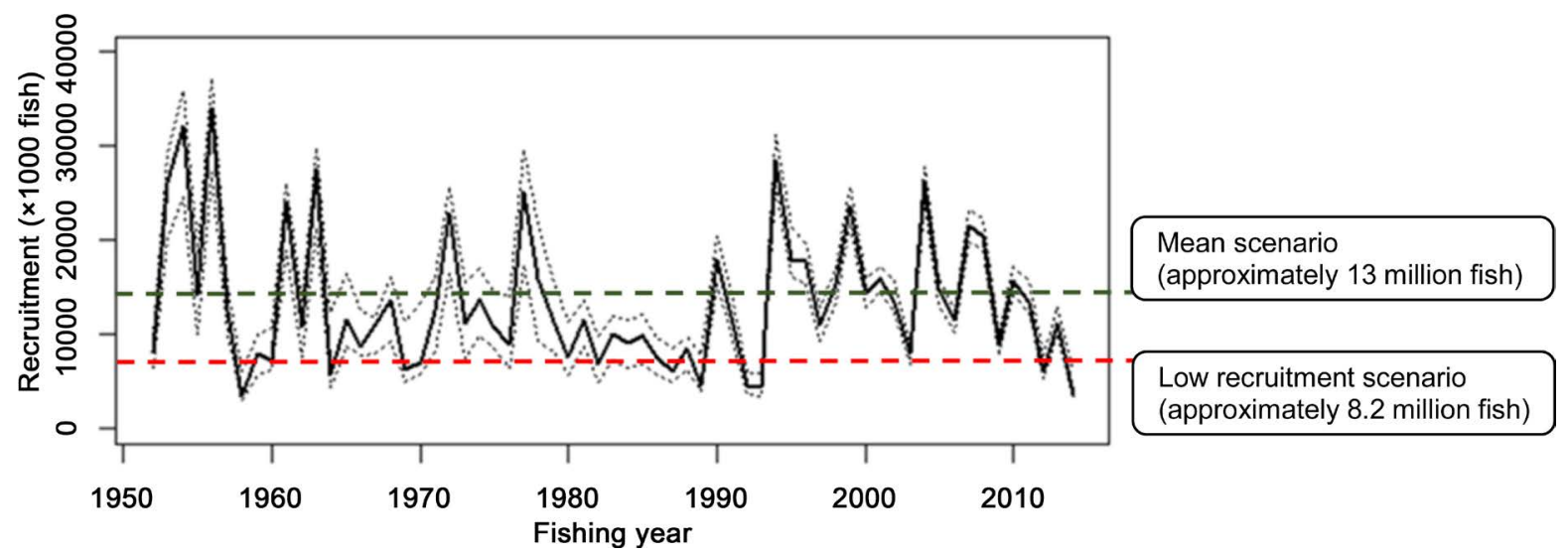

Note: The solid line indicates point estimate and dashed lines indicate the $90 \%$ confidential interval.

Figure 3. Pacific Bluefin Tuna recruitment [2].

Table 1. Forecast scenarios for Pacific Bluefin Tuna [18].

\begin{tabular}{ccc}
\hline Measures to limit fishing & $\begin{array}{c}\text { Low recruitment scenario } \\
\text { (approx. 8.2 million fish/year) }\end{array}$ & $\begin{array}{c}\text { Mean recruitment scenario } \\
\text { (approx. 13 million fish/year) }\end{array}$ \\
\hline No change & $0.5 \%$ & $98.0 \%$ \\
$50 \%$ additional cut in small fish & $79.4 \%$ & $100.0 \%$ \\
Fishing ban & $100.0 \%$ & $100.0 \%$ \\
\hline
\end{tabular}


Australia changed to become countries that support resource conservation alongside the decline of their domestic whaling industries, and in the face of pressure from domestic public opinion and nature conservation groups, also came to support the anti-whaling side in international society. Likewise, with regard to Pacific Bluefin Tuna, the former fishing country of The United States has now withdrawn from commercial fishing, and has consequently become an active promoter of fishing controls on Pacific Bluefin Tuna from the perspective of nature conservation.

With the increasing endangerment of Pacific Bluefin Tuna, the situation in which players supportive of nature conservation and marine resource conservation such as The United States, the EU, Australia, New Zealand, island countries and international NGOs are increasingly speaking out as the majority also recalls the shape of international anti-whaling opinion in the 1970s.

That is to say, international relations surrounding Pacific Bluefin Tuna resemble the process that lead to the IWC decision to ban commercial whaling in the 1970s and 1980s, and as things stand in international society, with the increasing danger of extinction, even countries that have taken a neutral position have come to support resource conservation, and it may be anticipated that international rules will be established through majority vote that lean strongly towards resource conservation by imposing a total ban on Pacific Bluefin Tuna fishing. The fact that the Japanese Government, despite the existence of this situation, has pushed for regulatory relaxation that ignores the resource conservation of Pacific Bluefin Tuna, may be considered to be behaviour that risks making enemies not only of anti-fishing countries, but even of neutral countries. In the event that international rules for resource conservation in the form of a total fishing ban on Pacific Bluefin Tuna are indeed established by majority vote, looking at the example of whaling, it may be anticipated that it will be extremely difficult for the fishing and consuming countries, as the minority, to change such rules which have been established in the name of nature conservation.

\section{Conclusions}

As stated above, similarities with the course of events that led to the 1982 total ban on commercial whaling can be seen in international relations surrounding the conservation and consumption of Pacific Bluefin Tuna, and if Japan continues to adopt policies which make light of resource conservation, it will lose the support not only of countries opposed to fishing but also of neutral countries, and a total ban on the fishing of Pacific Bluefin Tuna may result. Despite this, rampant illegal and unreported fishing has been detected this year in Japan which ignores even the fishing regulations introduced by the Fisheries Agency. The need of consumers to eat large quantities of Bluefin Tuna at cheap prices stands in the background of the rapid decrease in Bluefin Tuna resources to the present level. The competition between fishermen to catch small fish before they can grow large in order to supply Bluefin Tuna cheaply and meet this need may 
lead to a decrease in resource levels. This history of competitive fishing leading to overfishing also overlaps with the history of the whaling issue.

In future researches, the implication from the whaling issue could be applied to cases of other endangered species as a framework to predict the development of international relations and regulations regarding them. History of the whaling issue implies that a pro-consumption country will lose the support not only of countries opposed to the consumption but also of neutral countries if the country continues to adopt policies which make light of resource conservation. Sustainable use will only be possible when consumers consume responsibly.

\section{References}

[1] Sekiyama, T (2014) Coordination, Compromise, and Change: A Case of US-Japan Conflict over Commercial Whaling. International Relations and Diplomacy, 2, 310-322.

[2] ISC (2016) Stock Assessment of Pacific Bluefin Tuna 2016.

[3] Sekiyama, T. (2017) An Examination of Sustainable Management of Pacific Bluefin Tuna Stock. Journal of Environmental Protection, 8, 26-33. https://doi.org/10.4236/jep.2017.81003

[4] American Society of International Law (2001) US Sanction Against Japan for Whaling. The American Journal of International Law, 95, 149-152. https://doi.org/10.2307/2642050

[5] Birnie, P. (1985) International Regulations of Whaling: From Conservation of Whaling to Conservation of Whales and Regulation of Whale-Watching, New York, Oceana Publications.

[6] Ishii, A. and Okubo, A. (2007) An Alternative Explanation of Japan's Whaling Diplomacy in the post-Moratorium Era. Journal of International Wildlife Law and Policy, 10, 55-87. https://doi.org/10.1080/13880290701229911

[7] Kakinuma, T. (2007) A Comparative Study on Whaling Cultures: Between Japan and the USA. The Quarterly Report of Economics, 56, 1-43.

[8] Martin Jr., G.S. and Brennan, J.W. (1989) Enforcing the International Convention for the Regulation of Whaling: The Pelly and Packwod-Magnuson Amendments. Denver Journal of International Law and Policy, 17, 293-315.

[9] Nobuo, T. (2004) The Starting Point of the US Anti-Whaling Policy. Studies in Political Science and Economics, 41, 203-234.

[10] Sanada, Y. (2007) International Whaling Commission, Management of Marine Mammals, and the trAnsformation of US Whaling Policy. Journal of Cooperation Studies, 14, 139-159.

[11] Sumi, K. (1989) The Whale War between Japan and the United States: Problems and Prospects. Denver Journal of International Law and Policy, 17, 317-72.

[12] Pacific Islands Forum Fisheries Agency (FFA) (2011) Global Tuna Market \& Industry Dynamics_Full Report.

[13] Japanese Fisheries Agency (2014) Kongo no Geirui Hokaku Chosa no Jisshi Houshin no Gaiyou (Outline for Implementation of Research Whaling).

[14] The Pew Charitable Trusts and Greenpeace (2016). Statement to the Western and Central Pacific Fisheries Commission 12th Regular Session of the Northern Committee 29 August-2 September 2016, Fukuoka, Japan. 
[15] Tokyo Shimbun (2017) Bluefin Tuna: I Hope We Can Still Enjoy It in 100 Years. 8 September 2017.

[16] WCPFC (2017) NC13 Summary Report.

[17] WCPFC (2017) Reference Document for Review of CMM 2016-04 and for the Development of Harvest Strategies under CMM 2014-06 (Pacific Bluefin Tuna).

[18] ISC (2017) Summary of Additional PBF Projections.

\section{List of Abbreviations}

ISC: International Scientific Committee for Tuna and Tuna-like Species in the North Pacific Ocean

IWC: International Whaling Commission

WCPFC: Western and Central Pacific Fisheries Commission 